\title{
CLASSROOM READING HELPED PROGRAMS FOR COMIC MEDIA TO IMPROVE THE INTEREST OF READING BASIC SCHOOL STUDENTS
}

\section{Rohmah Suciningrum}

Universitas Sebelas Maret rohmahsuci82@gmail.com

\section{Article History}

accepted 09/07/2018

approved 01/08/2018

published 17/09/2018

\section{Keywords}

Interest of reading,

Classroom Reading

Program, Komik

\begin{abstract}
Reading is an important activity that is used as a habituation activity for students in elementary school. Classroom Reading Program is a systematic and structured classroom reading program. Comics is one medium that can be used to increase interest in reading learners. Classroom Reading The comic media assisted program is expected to increase students' reading interest in elementary schools. This research method is descriptive qualitative. Research data related to students' interest in reading through the application of classroom reading assisted program comic media collected through questionnaire instruments, then the results of questionnaires were analyzed based on Linkert guidelines. In addition to questionnaires, the techniques used to retrieve data are interviews, observation and documentation studies. The aim of the study was to find out how the application of Classroom Reading was a comic media assisted program in increasing students' reading interest. After the Classroom Reading the comic media assisted program was implemented, it was proven that students' interest in reading increased. The average increase in the interest of learners by $90 \%$.
\end{abstract}

Social, Humanities, and Education Studies (SHEs): Conference Series https://jurnal.uns.ac.id/shes

p-ISSN 2620-9284 e-ISSN 2620-9292 


\section{PENDAHULUAN}

Membaca adalah hal yang sangat penting dalam memajukan setiap pribadi manusia maupun suatu bangsa.. Namun sebuah persoalan membaca yang selalu mengemuka, terutama di kalangan pelajar, adalah bagaimana cara menimbulkan minat dan kebiasaan membaca.Dari pengamatan penulis di kelas ketika diberi pelajaran bahasa Indonesia khususnya membaca terlihat $50 \%$ peserta didik tidak tertarik, acuh tak acuh, beberapa peserta didik selalu bercakap-cakap dengan teman sebangkunya, sebagian besar peserta didik gaduh, dan bacaan baru selesai dalam waktu yang cukup lama.

Minat baca peserta didik cenderung menurun, kegiatan membaca tidak variatif, tidak ada tindak lanjut atau hanya asal membaca, ruang baca/ perpustakaan terpisah dengan ruang kelas, buku yang tersedia tebal dan miskin ilustrasi. Lemahnya tingkat kemampuan membaca pemahaman peserta didik merupakan kendala untuk mendapatkan nilai yang memuaskan, apalagi bila metode pembelajaran yang diterapkan guru kurang tepat, hal ini akan membuat nilai hasil belajar peserta didik semakin terpuruk berada jauh di bawah batas ketuntasan. Dari uraian di atas maka dapat disimpulkan bahwa tingkat kemampuan membaca pemahaman para peserta didik di sekolah dasar perlu mendapatkan perhatian serius. Salah satu cara agar peserta didik memiliki kemampuan membaca tinggi maka kebiasaan membaca perlu ditingkatkan.

Berdasarkan paparan di atas, maka rumusan masalah dalam penelitian ini adalah, 1) bagaimana penerapan Classroom Reading Program berbantuan mediakomik dalam meningkatkan minat baca peserta didik?, 2) Apakah penerapan Classroom Reading Program berbantuan media komik dapat meningkatkan minat baca peserta didik sekolah dasar?

\section{Classroom Reading Program}

Menurut kamus Bahasa Inggris Sandy Putra mengartikan istilah Classroom berarti ruang kelas atau ruang belajar di suatu sekolah, kata reading berarti membaca dan program berarti rencana atau daftar kegiatan, jika digabungkan tiga kata tersebut menjadi Classroom Reading Program yang berarti program membaca di kelas. Pada program ini Classroom Reading Program diartikan program membaca di kelas. Classroom Reading Program pertama dikenalkan di Indonesia pada awal tahun 2010 melaui Program membaca di kelas oleh DBE 2 USAID. Di Indonesia program ini disebut " Program Membaca di Kelas." (modul Classroom Reading Program,2010).

Dalam menjalankan kegiatan Classroom Reading Program memiliki tiga langkah yang disebut (Three steps to implement a program to read in class ) yaitu ; 1) Mengenalkan buku, kegiatan bisa dilakukan guru dengan melibatkan peserta didik mengenal, memanfaatkan, merawat dan menentukan aturan- aturan penggunaan buku-buku di dalam kelas. 2) Mengembangkan kegiatan pembelajaran dengan menggunakan buku-buku bacaan yang tersedia di dalam kelas. Penggunaan buku tidak terpancang pada buku materi pelajaran tetapi buku - buku bacaan yang sudah dikelompokan ke dalam mata pelajaran ; 3) Menciptakan kegiatan membaca yang dapat meningkatkan kreatifitas peserta didik. Kegiatan ini dapat membawa peserta didik dalam situasi belajar maka pembelajaran dirancang menggunakan model pembelajaran aktif, kreatif, efektif dan menyenangkan (PAKEM) berbantuan media Komik. Selanjutnya peserta didik dapat menggunakan buku-buku bacaan untuk kegiatan pembiasaan di sekolah.

\section{Media Komik}

Media Komik merupakan suatu kartun mengungkapkan sebuah karakter dan memerankan cerita dalam urutan yang erat, dihubungkan dengan gambar dan 
dirancang untuk memberikan hiburan kepada para pembaca. Peranan pokok komik dalam instruksional adalah kemampuannya dalam menciptakan minat peserta didik (Rohani, 2014:77-79). Wurianto (2009) media komik terdapat lima kelebihan komik sebagai berikut: 1) media komik dapat meningkatkan motivasi peserta didik selama pembelajaran; 2) media komik berupa gambar-gambar yang dapat meningkatkan kualitas pembelajaran; 3) media komik sebagai perantara yang bersifat permanen; 4) media komik dapat meningkatkan minat membaca serta mengarahkan kepada peserta didik untuk disiplin membaca terutama peserta didik yang tidak gemar membaca; 5) media komik merupakan gagasan atau ide bagian dari budaya popular.

Media komik termasuk kedalam media grafis. Media grafis itu sendiri merupakan suatu penyajian secara visual yang menggunakan titik-titik, garis-garis, gambar-gambar, tulisan-tulisan, atau simbol visual yang lain dengan maksud untuk mengikhtisarkan, mengambarkan dan merangkum suatu ide, data atau kejadian (Daryanto, 2010: 19). Fungsi khusus digunakannya media grafis adalah untuk menarik perhatian, memperjelas ide, mengilustrasikan atau menghiasi fakta yang mungkin akan cepat dilupakan atau diabaikan bila tidak digrafiskan begitu juga materi pelajaran yang hanya disajikan berupa teks atau tulisan. Komik adalah suatu bentuk sajian cerita dengan seri gambar yang lucu. Buku komik menyediakan cerita-ceritanya yang sederhana, mudah ditangkap dan dipahami isinya sehingga sangat digemari baik oleh anak-anak maupun orang dewasa. Menurut fungsinya komik dibedakan atas komik komersial dan komik pendidikan. Komik pendidikan banyak diterbitkan oleh industri, dinas kesehatan, lembaga-lembaga non profit. (Daryanto, 2010:27)

\section{Minat Baca}

Minat membaca adalah suatu dorongan atau keinginan untuk membaca. Guru sebagai pendidik wajib berpartisipasi dalam menumbuhkan minat membaca peserta didik. Anak-anak yang tumbuh dengan minat baca tinggi diyakini akan tumbuh menjadi generasi yang berkualitas. Menumbuhkan minat baca pada anak merupakan langkah untuk menciptakan generasi yang berkualitas di kemudian hari. Khundaru dan St.Y.Slamet (2012:64) berpendapat bahwa membaca bukanlah sekedar menyuarakan lambang-lambang tertulis tanpa menpersolkan apakah rangkaian kata atau kalimat yang dilafalkan tersebut dipahami atau tidak, melainkan lebih daripada itu.

\section{METODE PENELITIAN}

Metode penelitian yang digunakan dalam penelitian ini adalah jenis deskriptif Kualitatif. Penelitian kualitatif merupakan penelitian yang bermaksud memahami fenomena tentang apa yang dialami oleh subjek penelitian secara holistik baik itu perilaku, motivasi, tindakan dan dengan cara deskripsi dalam bentuk kata-kata dan bahasa pada suatu konteks yang alamiah dan memanfaatkan berbagai metode ilmiah ( Moleong 2017: 6). Alasan pemilihan desain penelitian ini karena penulis berupaya untuk memperhatikan makna-makna tindakan dari kejadian orang yang ingin di pahami.Selain menggunakan angket penelitian ini juga menggunakan teknik wawancara, observasi dan studi dokumentasi untuk pengumpulan data primer maupun skunder.. Alat yang bisa digunakan dalam observasi adalah lembar pengamatan, 
ceklist, catatan kejadian dan lain-lain. Tenik analisa data yang digunakan adalah menggunakan model Miles dan Huberman (Sugiyono, 2013 : 91). Kegiatan tersebut terdiri dari 3 (tiga) tahap yakni reduksi data, penyajian data, dan verifikasi data. Kesimpulan awal yang dikemukakan masih bersifat sementara, dan akan berubah bila tidak ditemukan bukti-bukti yang kuat yang mendukung pada tahap pengumpulan data berikutnya. Uji keabsahan data dalam penelitian ini menggunakan empat uji keabsahan data kualitatif yaitu :1)credibility (validitas internal). 2)transferability (validitas eksternal). 3) dependability (reliabilitas). 4)confirmability (obyektivitas) (Sugiyono, 2013: 364).

\section{HASIL DAN PEMBAHASAN}

Hasil penelitian dari penerapan Classroom Reading Program berbantuan media komik bagi peserta didik Sekolah dasar diperoleh dari hasil angket, wawancara, observasi dan studi dokumentasi.

Pengumpulan data dengan angket menggunakan pedoman sebagai berikut:

\section{Tabel1PedomanPemberianSkor}

\begin{tabular}{clcc}
\hline \multirow{2}{*}{ No } & Alternatif & \multicolumn{2}{c}{ Skor } \\
\cline { 3 - 4 } & Jawaban & Positif (+) & Negatif (-) \\
\hline 1 & Sangat setuju & 4 & 1 \\
\hline 2 & Setuju & 3 & 2 \\
\hline 3 & Kurang setuju & 2 & 3 \\
\hline 4 & Tidak setuju & 1 & 4 \\
\hline \multicolumn{3}{c}{ Sumber: Sugiyono } & $(2010$, hal. 135)
\end{tabular}

Total skor selanjutnya diinterpretasikan sehingga minat peserta didik dapat dikelompokkan berdasarkan kategori yang telah ditentukan. Adapun pedoman interpretasi skor tercantum dalam tabel di bawah ini:

\begin{tabular}{lll} 
& \multicolumn{2}{c}{ Tabel 2 Pedoman Interpretasi Skor } \\
\hline No & Interval Skor & \multicolumn{1}{c}{ Kriteria } \\
\hline 1 & $0 \%-19,99 \%$ & sangat kurang \\
\hline 2 & $20 \%-39,99 \%$ & Kurang \\
\hline 3 & $40 \%-59,99 \%$ & cukup / netral \\
\hline 4 & $60 \%-79,99 \%$ & setuju/baik/suka \\
\hline 5 & $80 \%-100 \%$ & sangat (setuju/baik/suka) \\
\hline \multicolumn{3}{c}{ Sumber: Choizes ( 2017) }
\end{tabular}

Berdasarkan hasil angket dari peserta didik diperoleh data sebagai berikut:

Tabel3Tabel Penerapan Classroom Reading Program Berbantuan Media Komik

\begin{tabular}{clcc}
\hline No & \multicolumn{1}{c}{ Indikator } & $\begin{array}{c}\text { ResponPeserta } \\
\text { didik }\end{array}$ & Kriteria \\
\hline $\mathbf{1}$ & $\begin{array}{l}\text { Meninjamlebih dari5 Komik perminggu pada } \\
\text { saat membaca di ruang kelas. }\end{array}$ & $90 \%$ & Sangat baik \\
\hline $\mathbf{2}$ & Meluangkanwaktu untuk membacasetiap hari & $100 \%$ & Sangat baik \\
\hline
\end{tabular}




\begin{tabular}{llll}
\hline & di dalam kelas & & \\
\hline $\mathbf{3}$ & Merasa senang saat membaca & $83 \%$ & Sangat baik \\
\hline $\mathbf{4}$ & Merasa mendapatkan manfaat dari membaca & $85 \%$ & Sangat baik \\
\hline $\mathbf{5}$ & Ingin lebih banyak membaca buku & $83 \%$ & Sangat baik \\
\hline & Rerata & $90 \%$ & Sangat baik \\
\hline
\end{tabular}

Dari tabel di atas dapatdiketahui bahwasebagian besar peserta didik sudah berminat dalam melakukan kegiatan membaca melalui penerapan Classroom Reading Program berbantuan media komik. Hampir seluruh peserta didik sudah rutinmeminjam dan memanfaatkanKomikminimal lima komiksetiap hari. Prosentaseskor peserta didik yang berada pada kisaran $81 \%-100 \%$ dapat diartikan bahwaminat peserta didik dalammemanfatkan Komik dalam kegiatan membaca sangat baik, meskipun sebagianpeserta didik melakukanhal tersebutkarena himbauan dari guru, sehingga saat merespon indikator rasa senang dalam membaca dan motivasi untuk terus ingin membaca, respon peserta didiktidak sebaik antusiasme dalam memanfaatkan Komik.

Data mengenaipenerapan Classroom Reading Program berbantuan media komikdikumpulkan melalui angket menunjukkanbahwasebagian pesrta didik telah berada pada kriteriasangat tinggi. Data tersebut selaras dengan pendapat yang mengemukakan: "cara menumbuhkan minat membaca anakadalah: (1)memberikan contoh, (2) membacakan cerita kepada anak, (3) membiasakan anak membaca buku cerita yang disukainya secara konsisten selama 21 hari” , hal ini dikaitkan dengan cara meningkatkan IQ anak dengan membiasakan membaca. (Gunawan., 2005, hal. 8). Pemanfaatan Komik sebagai daya tarik dalam kegiatan membacaberdasarkan data angket menunjukkan telah adanya peningkatan yang cukupsignifikan. Peserta didik merasatertarik untuk melakukan kegiatan membaca. Rerata minat peserta didik berdasarkan lima indikator di atasadalah $90 \%$, yang dalam pedoman interpretasi skor dapat dikategorikan menjadi "sangat baik".

Hasil wawancara dari narasumber memberikan informasi bahwa ada peningkatan dalam kegiatan membaca pada diri peserta didik di sekolah dasar. Peserta didik menjadi antusias dalam membaca berawal dari penerapan Classroom Reading Program dengan dibantu oleh media komik yang menarik. Berdasarkan dokumentasi menunjukkan bahwa peserta didik mengalami peningkatan dalam kegiatan membaca. Berawal dari membaca komik mereka mulai tertarik untuk membaca buku selain komik. Dokumentasi didapatkan dari daftar peminjam yang menjelaskan mengenai jenis buku yang dipinjam oleh peserta didik. Data angket juga didukung dengan data wawancara dan observasi pada peserta didik. Hasil dari wawancara dan observasi menunjukkan bahwa penerapan Classroom Reading Program berbantuan media komik sangat bermanfaat untuk menarik minat peserta didik dalam membaca. Peserta didik menjadi lebih semangat dalam membaca buku dalam bentuk komik tanpa adanya paksaan. Hasil penelitian yang didapatkan sependapat dengan peneltian terdahulu yang dilakukan oleh Wardani. Penelitian tentang media komik pernah dilakukan oleh Wardani (2012), salah seorang mahasiswa jurusan Sosiologi di Universitas Negeri Semarang. Penelitian yang dilakukan di Sekolah Menengah Atas (SMA) penggunaan media komik dalam pembelajaran sosiologi pada pokok bahasan masyarakat multikultural ini, menunjukkan hasil 
bahwa terdapat peningkatan hasil belajar peserta didik dengan menggunakan media komik yang terlihat dari aktifnya peserta didik dikelas.

\section{KESIMPULAN}

Berdasarkan data yang diperoleh selama penelitian, maka dapat disimpulkan bahwa penerapan Classroom Reading Program berbantuan media komik sangat bermanfaat untuk menarik minat peserta didik dalam melaksanakan kegiatan membaca. Peserta didik merasa memiliki minat yang tinggi dalam membaca dengan memanfaatkan media Komik. Peserta didik yang semula belum mempunyai kebiasaan membaca, melalui penerapan Classroom Reading Program berbantuan media komik sudah mempunyai kebiasaan membaca hampir setiap hari. Minat peserta didik dalam membaca relatif tinggi dengan menggunakan media Komik, yaitu mencapai rerata sebesar 90\%. Penerapan Classroom Reading Program berbantuan media komik hendaknya terus ditingkatkan sehingga minat membaca anak semakin meningkat pula.

\section{DAFTAR PUSTAKA}

Choizes, E. (2017, April 11). Pengertian Skala Likert dan Contoh Cara Hitung Kuesionernya. Diambil kembali dari Diedit: https://www.diedit.com/skala-likert/

Creswell, John W. 2017. Penelitian Kualitatif dan Desain Riset. Yogyakarta: Pustaka Pelajar.

Daryanto. 2010. Media Pembelajaran. Yogyakarta : Gava Media

DBE 2 - USAID 2010. Modul Pelatihan Program membaca. Jakarta: USAID

Khundaru Sadhono dan St.Y Slamet.2012.Meningkatkan Keterampilan Berbahasa Indonesia Teori dan Aplikasi. Bandung: Karya Putra Darwanti

Moleong, J Lexy. 2017. Metodologi Penelitian Kualitatif.Bandung: PT Remaja RosdakaryaPendidikan Dasar dan Menengah.

Rohani, Ahmad. 2014.Media Intruksional Edukatif. Jakarta: PT Rineka Cipta..

St.Y. Slamet. 2012.Dasar-Dasar Keterampilan Berbahasa Indonesia.Surakarta: UNS Press

Sugiyono. 2012. Metode Penelitian Kuantitatif, Kualitatif, dan R\&D. Bandung: Alfabeta.

Wardani, Tri. 2012. Penggunaan Media Komik Dalam Pembelajaran Sosiologi Pada Pokok Bahasan Masyarakat Multikultural. Journal Unnes Vol.V, no 1

Wurianto, Eko. 2009. Komik Sebagai Media Pembelajaran. Jakarta: Pustaka Jaya 